\title{
Cronkhite - Canada Syndrome without Colonic Polyps
}

A 65-year-old male presented with a history of diarrhea, vomiting, and weight loss of three months' duration. The diarrhea was watery, and there were five to eight episodes per day. The physical examination showed cachexia, pedal edema, loss of hair on the scalp, onychodystrophy, and bilateral pedal edema. Serum albumin was $24 \mathrm{~g} / \mathrm{l}$.

Upper gastrointestinal endoscopy showed multiple sessile polyps in the stomach (Figure 1). Biopsy of the polyps revealed intense edema of the lamina propria, and elongation and tortuosity of the foveolae, with marked cystic changes in the pits and glands (Figure 2). Some of the cysts were ruptured, and showed muciphages. Colonoscopy did not reveal any polyps. A highcalorie blended diet was given through a nasogastric tube. Within two weeks, the pedal edema disappeared, and the patient's hair started growing. After one month there was considerable hair growth, and the patient was able to walk by himself. He died suddenly of myocardial infarction.

Except for the case described by Koehler et al. (1), extensive polyposis of the colon is the rule in patients with CronkhiteCanada syndrome (1). However, a forme fruste of CronkhiteCanada syndrome in which the patient only had superficial cystic gastritis and alopecia, has been reported (2).

The exact cause of Cronkhite-Canada syndrome is not known. Since the gastric mucosa in Cronkhite-Canada syndrome and Ménétrier's disease are morphologically similar and both conditions are associated with a protein-losing enteropathy, it appears that Cronkhite-Canada syndrome may represent a more severe form of Ménétrier's disease, and that there may be a continuum between the two (3).

Many cases of Cronkhite-Canada syndrome have had a fatal outcome. However, in one case complete remission occurred when the patient was given enteral nutrition (4). A temporary improvement has also been noted with parenteral nutrition (5). Due to reports of remission, it has been suggested that Cronkhite-Canada syndrome might have a nutritional, infectious, or toxic cause (3). However, the resemblance of the pathological lesion to colitis cystica profunda, which is found in pellagra, and the response to nutritional supplements that is seen, points toward a nutritional deficiency.

S. P. Misra, V. Misra, M. Dwivedi, P. A. Singh, S. C. Gupta Dept. of Gastroenterology, Dept. of Pathology,

M.L.N. Medical College, Allahabad, India

\section{References}

1. Koehler PR, Kyaw MM, Fenlon JW. Diffuse gastrointestinal polyposis with ectodermal changes: Cronkhite-Canada Syndrome. Radiology 1972; 103: 589-94.

2. Lipper S, Kahn LB. Superficial cystic gastritis with alopecia: a forme fruste of the Cronkhite-Canada syndrome. Arch Pathol Lab Med 1977; 101: 432-6.

3. Rubin M, Tuthil RJ, Rosato EF, et al. Cronkhite-Canada syndrome: report of an unusual case. Gastroenterology 1980; 79: $737-41$

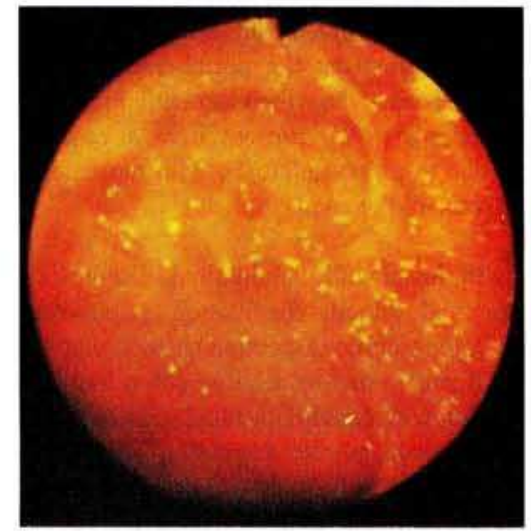

Figure 1: Endoscopic appearance of the stomach. Note the presence of multiple cystic sessile polyps.



Figure 2: Gastric biopsy, showing edema of the lamina propria with cystic dilation of the gastric pits (hematoxylin-eosin, $\times 40$ ).

4. Russell DM, Bhathal PS, John JBS. Complete remission in Cronkhite-Canada syndrome. Gastroenterology 1983; 85: $180-5$.

5. Miyoshi M, Fujii H, Iwasa N, et al. Two autopsy cases of diffuse gastrointestinal polyposis with ectodermal changes: Cronkhite-Canada syndrome. Am J Gastroenterol 1975; $64: 357-64$.

Corresponding Author S. P. Misra, M.D., D.M. Dept. of Gastroenterology M.L.N. Medical College Allahabad 211001 India Fax: +91-532-611420 